\title{
STREAM FISH, WATER AND HABITAT QUALITY IN A PASTURE DOMINATED BASIN, SOUTHEASTERN BRAZIL
}

\author{
CASATTI, L. ${ }^{1}$, LANGEANI, F. ${ }^{1}$, SILVA, A. M. ${ }^{2}$ and CASTRO, R. M. C. ${ }^{3}$ \\ ${ }^{1}$ Laboratório de Ictiologia, Departamento de Zoologia e Botânica, Universidade Estadual Paulista - UNESP, \\ Rua Cristóvão Colombo, 2265, CEP 15054-000, São José do Rio Preto, SP, Brazil \\ ${ }^{2}$ Departamento de Engenharia Ambiental, Unidade Diferenciada, Universidade Estadual Paulista - UNESP, \\ Av. Três de Março, 511, CEP 18087-180, Sorocaba, SP, Brazil \\ ${ }^{3}$ Laboratório de Ictiologia de Ribeirão Preto - LIRP, Departamento de Biologia, FFCLRP, Universidade de São Paulo, \\ Av. Bandeirantes, 3900, CEP 14040-901, Ribeirão Preto, SP, Brazil \\ Correspondence to: Lilian Casatti, Laboratório de Ictiologia, Departamento de Zoologia e Botânica, \\ Universidade Estadual Paulista - UNESP, Rua Cristóvão Colombo, 2265, CEP 15054-000, \\ São José do Rio Preto, SP, Brazil, e-mail: lcasatti@ibilce.unesp.br
}

Received January 17, 2005 - Accepted March 1, 2005 - Distributed May 31, 2006

(With 3 figures)

\begin{abstract}
A fish survey in 35 stream reaches (from $1^{\text {st }}$ to $3^{\text {rd }}$ order) with physicochemical and habitat assessment in the São José dos Dourados system, southeastern Brazil, was conducted. Most of the basin land cover (77.4\%) is used for pasture. From the sampled stream reaches, 24 were of good physicochemical quality, 10 of fair quality, and only one of poor quality. A habitat assessment showed that 10 stream reaches were considered fair, 22 were poor, and 3 were very poor. Fifty species were collected and their abundances showed strong correlation with habitat descriptors. In addition to the correlation between fish abundance and habitat, some species also showed optimal distribution related to the degree of physical habitat conservation. Streams located in this region experience organic pollution, but the most important aspect is the decline of the instream physical habitat condition, especially in first order streams, which negatively affects coarse substrates and water column dependent fish species. Effluent control, riparian vegetation restoration programs, siltation control and adequate sustainable soil use are practices which could mitigate such impacts.
\end{abstract}

Keywords: Upper Paraná, integrity, physicochemical, conservation, indices.

\section{RESUMO}

\section{Ictiofauna de riachos, qualidade da água e do hábitat em uma bacia hidrográfica dominada por pastagens, Sudeste do Brasil}

A ictiofauna de 35 trechos de riachos (de $1^{\mathrm{a}}$ a $3^{\mathrm{a}}$ ordem) no sistema do Rio São José dos Dourados, Sudeste do Brasil, foi estudada juntamente com a avaliação físico-química e física do hábitat. Na região estudada, 77,4\% do solo é utilizado para pastagens. Quanto à avaliação físico-química da água, 24 trechos foram classificados como bons, 10 como regulares e um como pobre; quanto à avaliação física do hábitat, 10 foram considerados regulares, 22 como pobres e 3 como muito pobres. Cinqüienta espécies foram coletadas e suas abundâncias apresentaram forte correlação com descritores do hábitat. Em adição a esta correlação, observou-se que algumas espécies também demonstraram sua distribuição ótima coincidente com o grau de conservação do hábitat físico. Os riachos dessa região estão expostos a impactos provenientes de poluição orgânica, mas especialmente pequenos riachos de primeira ordem estão seriamente afetados pela perda de qualidade física do hábitat, que, negativamente, afeta tanto espécies de peixes dependentes de substratos rochosos como espécies que exploram a coluna d'água. Controle da entrada de efluentes, programas adequados de restauração da vegetação ripária, controle do aporte de sedimento e uso adequado e sustentável do solo são práticas que podem mitigar tais impactos.

Palavras-chave: Alto Paraná, integridade, físico-químico, conservação, índices.

Braz. J. Biol., 66(2B): 681-696, 2006 


\section{INTRODUCTION}

An effective assessment of lotic condition requires comprehending the multiple causes of stress on the aquatic biota, including habitat loss and degradation, the spread of non-native species, overexploitation, secondary extinctions, chemical and organic pollution, and global climate change (Allan \& Flecker, 1993). The accuracy in detecting such impacts is clearly limited, but the search for adequate indicators at several levels (i.e. chemical, physical, and biological) has been carried out for nearly a century (e.g., Forbes \& Richardson, 1919). Dams and anthropogenic deforestation at levels ranging from massive projects to local cumulative alterations are important forces worldwide that are modifying both landscapes and waterways (Allan \& Flecker, 1993).

With the exception of some remote Amazonian rivers, most aquatic environments have been altered by human activities in Brazil (Tundisi \& Barbosa, 1995), including wetland drainage, dams, road building, and deforestation for human settlements and intensive agriculture. All of these modifications had a negative impact on the hydrology, vegetation cover, and terrestrial-aquatic linkages (Allan \& Flecker, 1993) of the affected systems. A prime example is the State of São Paulo, the most industrialized and populous in Brazil that retains only $14 \%$ of its original vegetation (Zorzetto et al., 2003), which originally was represented primarily by Semi-Deciduous forests, Atlantic rainforests, and Savannah (Cerrado). These last two biomes were considered biodiversity hotspots for conservation priorities by Myers et al. (2000). Semi-Deciduous forests, which were previously the main vegetation coverage of the western portion of the State are now restricted to small, unconnected, residual fragments. This region is drained by the lower rio Tietê, the rio São José dos Dourados, and the rio Turvo, and few studies reported stream fish assemblages in these river basins (Garutti, 1988; Lemes \& Garutti, 2002; Castro et al., 2004). We surveyed the São José dos Dourados system as part of a project aiming to develop a fish index of biotic integrity for the upper rio Paraná headwaters and streams. The most important step in the IBI development is to choose and integrate metrics that reflect diverse responses of biological systems to human actions (Karr \& Chu, 1999). Because ecology and biology of stream fish in that region are poorly known, in this study we investigated fish assemblage structures in a wide range of physicochemical and habitat conditions, in randomly selected places in order to detect the main kinds of impacts on the fish fauna.

\section{STUDY AREA AND REGIONAL REFERENCE AREA}

The São José dos Dourados system includes the river basin plus some small tributaries of the left margin of the rio Paraná. The system is located in the Serra Geral formation, composed of basaltic and sedimentary rocks of the Cauiá and Bauru groups. The sandy Botucatu and Pirambóia formations (both belonging to the São Bento group) are the aquifers of the region (IPT, 2000). The climate is hot tropical (Nimer, 1989), with a wet season from October to March (January and February are the wettest months, with $54 \%$ of the annual rainfall), and a dry season, extending from April to September (Barcha \& Arid, 1971). The maximum mean temperature $\left(31{ }^{\circ} \mathrm{C}\right)$ occurs in January, and the minimum average $\left(13^{\circ} \mathrm{C}\right)$ occurs in July (IPT, 2000).

We adopted the regional reference concept to calibrate physicochemical and habitat descriptors, a more adequate design when monitoring is applied to a watershed or river basin (Barbour et al., 1999). The most important reference area was the quasi pristine Morro do Diabo State Park $\left(22^{\circ} 27^{\prime}\right.$ to $22^{\circ} 40^{\prime} \mathrm{S}, 52^{\circ} 10^{\prime}$ to $\left.52^{\circ} 22^{\prime} \mathrm{W}\right)$, that encompasses approximately 33,000 ha, in the municipality of Teodoro Sampaio, Pontal do Paranapanema region, southwestern São Paulo state. Four streams within the park were previously studied by Casatti et al. (2001) and Casatti (2002, 2004). The park's monthly rainfall varied from $14.7 \mathrm{~mm}$ (May 2000) to $361 \mathrm{~mm}$ (December 2000) and temperatures ranged from $-1.2{ }^{\circ} \mathrm{C}$ (July 2000) to $37.8{ }^{\circ} \mathrm{C}$ (October 2000) (data from the weather station in the park). Physicochemical unpublished data recorded in the Morro do Diabo State Park streams were also provided by Daniela M. L. da Silva. Additional reference areas included also relatively less impacted streams studied in the upper Rio Paraná basin by Castro et al. (2003, 2004).

\section{MATERIAL AND METHODS}

Thirty-five sites of first to third order (according to Strahler, 1957, map scale 1:50,000) 
were selected using a random approach (Kasyak, 2001). The number of sites was approximately proportional to the total length in $\mathrm{km}$ for a particular stream order (Roth et al., 1997). One site was selected for each $100 \mathrm{~km}$ of length order, for a total of 22 first order, nine second order, and four third order sites. Following Kasyak (2001), a $75 \mathrm{~m}$ stream reach was chosen at each site with the aim of including all available macrohabitats. All stream reaches were sampled during the beginning of a single dry season (March to June, 2003) to minimize seasonal effects.

\section{Land cover}

The land cover map of the São José dos Dourados River system was developed by digitally supervised classification of two TM/Landsat5 images (path-row: 222/74 and 221/74 already georeferenced), using the maximum likelihood method (Eastman, 2001; Lillesand \& Kieffer, 2000). The images of the study area (August 1996) were acquired from the Instituto Nacional de Pesquisas Espaciais (Brazil). Bands 3, 4, and 5 were digitally processed to produce a land cover map with the following categories: pasture, perennial crops, remaining natural vegetation, sugar-cane, reforestation, water-bodies, annual crops, bare soil, urban locations, and others. Training sites were identified using field observations and internet data (www.cati.sp.gov.br) and the classification accuracy was checked using a field survey. Sixty randomly selected points were visited, and the Kappa Index of Agreement (Eastman, 2001) was 0.88, where $90 \%$ of the points had corresponding land use.

\section{Fish}

Fish were collected during two electrofishing passes (modified from Mazzoni et al., 2000; Castro et al., 2003), fixed in $10 \%$ formalin and later transferred to $70 \%$ ethanol. All specimens were deposited in the ichthyological collection of the Departamento de Zoologia e Botânica da Universidade Estadual Paulista, São José do Rio Preto, Brazil (DZSJRP 5833 to 6190).

\section{Water and habitat quality}

The combination of water quality and physical description can provide insight to the presence of chemical and non-chemical stressors to the stream ecosystem and for this reason we analyzed both components in separate ways, always comparing them to regional reference conditions (Barbour et al., 1999). In a broad sense, habitat incorporates all aspects of physical and chemical constituents along with the biotic factors, but following Barbour et al. (1999), we consider habitat as the instream and riparian zone that influences the structure and function of the ichthyocenosis.

A water quality index for small streams (Stream Water Index, SWI) of the upper Rio Paraná basin is herein proposed and includes physicochemical descriptors usually linked to fish health, specifically dissolved oxygen, conductivity, $\mathrm{pH}$, turbidity (all measured through digital meter Horiba $^{\circledR}$, model U-10), orthophosphate, nitrate, and ammonia (all analyzed in laboratory). In addition, water odors and water surface oils were also registered (Barbour et al., 1999) as indicators of possible human disturbance of a stream reach. Scores 4 to 1 were determined based on their deviation from the reference conditions and the average final score for each site was classified in four categories (Table 1).

For the physical assessment of the habitat, a visual-based habitat approach was conducted. Many protocols are applied around the world, all of them including descriptors which describe the stream micro/macro features, riparian condition, and bank structure (Barbour et al., 1999). We combined the protocols proposed by Roth et al. (1996), Barbour et al. (1999), and Kasyak (2001). Scores were established a priori according to reference conditions, usually separating sites into high-gradient and low-gradient reaches. To minimize subjectivity, the same person evaluated all sites. All descriptors were evaluated and rated on a numerical scale of 0 to 20 for each sampling reach (see Habitat Form on Appendix). The sum of all scores represented four habitat integrity categories (Table 2) of the Physical Habitat Index (PHI). Habitat descriptors are:

1. Substrate stability. This includes the degree of cover provided by natural structures in each stream, such as cobble (in riffles), large rocks, fallen trees, logs and branches that are available as shelter, feeding, or spawning and nursery sites. Decreases in the variety and abundance of such structures render the habitat more homogeneous, thereby decreasing habitat diversity and recovery 
TABLE 1

Scores for physicochemical water descriptors for small streams in the upper rio Paraná basin, southeastern Brazil. SWI (stream water index) is the total score for a site: good (36-30); fair (29-23); poor (22-16); and very poor (15-9).

\begin{tabular}{|l|c|c|c|c|}
\hline \multicolumn{1}{|c|}{ Descriptors } & Score 4 & Score 3 & Score 2 & Score 1 \\
\hline Dissolved oxygen $(\mathrm{mg} / \mathrm{l})$ & $\geq 6.0$ & $5.0-5.9$ & $4.0-4.9$ & $<4.0$ \\
\hline Conductivity $(\mu \mathrm{S} / \mathrm{cm})$ & $\leq 50$ & $51-100$ & $101-150$ & $>150$ \\
\hline $\mathrm{pH}$ & 6 to 9 & $5.0-5.9$ & $4.0-4.9$ & $<4.0$ \\
\hline & & $9.1-10.0$ & $10.1-11.0$ & $>11.0$ \\
\hline Turbidity $(\mathrm{NTU})$ & $\leq 40$ & $41-150$ & $151-300$ & $>300$ \\
\hline Nitrate $(\mathrm{mg} / \mathrm{l})$ & $\leq 1.0$ & $1.1-1.5$ & $1.6-1.75$ & $>1.75$ \\
\hline Ammonia $(\mathrm{mg} / \mathrm{l})$ & $\leq 0.01$ & $0.02-0.5$ & $0.6-1.0$ & $>1.0$ \\
\hline Orthophosphate $(\mathrm{mg} / \mathrm{l})$ & $\leq 0.03$ & $0.04-0.5$ & $0.6-1.0$ & $>1.0$ \\
\hline Odor & normal & - & - & $\begin{array}{c}\text { sewage, petroleum, } \\
\text { chemical, dead fish }\end{array}$ \\
\hline Surface oils & absent & - & - & present \\
\hline
\end{tabular}

TABLE 2

Descriptions of stream physical habitat condition (adapted from Roth et al., 1996).

\begin{tabular}{|l|c|l|}
\hline Categories & Sum of scores & \multicolumn{1}{c|}{ Description } \\
\hline Good & $180-136$ & $\begin{array}{l}\text { Comparable to minimally disturbed reference streams. Falls within upper 75\% } \\
\text { of theoretical reference condition. }\end{array}$ \\
\hline Fair & $135-91$ & $\begin{array}{l}\text { Some aspects of physical habitat may not resemble those found in minimally } \\
\text { disturbed streams. Falls within the lower portion of the range of the theoretical } \\
\text { reference sites (75-50\% of the reference). }\end{array}$ \\
\hline Poor & $90-46$ & $\begin{array}{l}\text { Significant deviation from minimally disturbed reference conditions, with many } \\
\text { aspects of physical condition not resembling those of minimally disturbed } \\
\text { streams, indicating some degradation (50-25\% of the reference). }\end{array}$ \\
\hline Very poor & $45-0$ & $\begin{array}{l}\text { Strong deviation from minimally disturbed reference conditions, with most } \\
\text { aspects of physical condition not resembling those found in minimally disturbed } \\
\text { streams, indicating severe degradation (below 25\% of the reference). }\end{array}$ \\
\hline
\end{tabular}

potential. Logs and branches in low gradient streams are often critical habitats for such purposes (Barbour et al., 1999);

2. Velocity and depth variability. The different combinations of velocity and depth represent another component of habitat diversity. High gradient streams often show four patterns of flow: slow/deep, slow/shallow, fast/deep, fast/shallow. Low gradient streams show four patterns of pools: large/shallow, large/ deep, small/shallow, small/deep (Barbour et al., 1999; Kasyak, 2001);

3. Flow stability. This represents the occurrence of natural and continuous flows versus flashy or ephemeral flow (Roth et al., 1996), such as typically found in areas with dams, obstructions, diversions for irrigation or during droughts;

4. Bottom deposition. Fine sediments accumulate mainly in pools, but may also embed in riffles, or create islands, point bars, or embayments. Depending on the channel slope, an increase in fine sediment indicates a less suitable environment for aquatic biota (Barbour et al., 1999); however, islands, point bars, and embayments increase channel complexity;

5. Combinations of pool-riffles-runs. This describes the variety of macrohabitats present; i.e. the combinations between pools, riffles, runs, and small marginal pools, against the predominance of channelized reaches (Roth et al., 1996); 
6. Channel alteration. Measures large-scale changes in the shape of the stream channel such as artificial embankments, artificial bank stabilization, channelization, and dredging (Barbour et al., 1999);

7. Streamside cover. Riparian zones are areas along water bodies, often with flood tolerant plants. When these zones support complex woody vegetation, they play a vital role in the structure and maintenance of physical habitat, energy flow, and aquatic assemblage composition. Riparian vegetation buffers against siltation, and elevated pollutants and water temperature, while providing habitat, nutrient input, and shelter and substrate for microorganisms (Millard et al., 1999; Barbour et al., 1999). The limits of the riparian zone are not easily defined and may vary with the season (Lima \& Zakia, 2000). There is no definitive method to establish the minimal riparian width for satisfactorily protecting water courses (Bren, 1993). For temperate streams in Ontario, Canada, Barton et al. (1985) defined a minimum buffer zone of $18 \mathrm{~m}$ from each bank. In Australia, Clinnick (1985) recommended 30 m. For Maryland streams, Kasyak (2001) proposed at least $50 \mathrm{~m}$, but FEMAT (1993) proposed a $70 \mathrm{~m}$ minimum buffer zone in the northwest USA. Brazilian legislation requires a minimum of $30 \mathrm{~m}$ of riparian vegetation for water bodies $10 \mathrm{~m}$ wide. In the absence of scientific consensus concerning the ideal riparian width, we used the minimal limits required by Brazilian laws. The mere presence of riparian vegetation is not indicative of natural conditions, since the presence of non-native species (Roth et al., 2001) and the absence of larger trees indicate a decline of integrity. This metric was consequently scored considering both the width and integrity of riparian vegetation;

8. Bank vegetative stability. Measures the extent of the streambank surface covered with vegetation or rubble, both of which provide protection from erosion (Roth et al., 1996; Barbour et al., 1999); and

9. Bank stability. This metric verifies whether stream banks are eroded, thereby including their potential for erosion. Higher potential for erosion is found in steeper and therefore more unstable banks. Erosion signs include crumbling, unforested banks, exposed roots and exposed soil. Each bank is evaluated separately (Barbour et al., 1999; Kasyak, 2001).

\section{Data analysis}

In order to ordinate the information about species abundance along sites, a detrended correspondence analysis (DCA) was conducted, using the option of 26 segments in the PCOrd software (McCune \& Mefford, 1999). Following Cao et al. (1998) rare species were not excluded from ordination because of the importance of this class of species in bioassessment. The mean velocity, mean depth, amount of riparian coverage (absent, present, or abundant), amount of marginal vegetation in contact with water (absent, present, or abundant), and predominant substrate (sand, sand/gravel, or sand/gravel/woody debris) were correlated with an ichthyocenosis structure using the Mantel test and Euclidean Distance for the abiotic matrix and Morisita-Horn for the species matrix; comparisons were made with the option of normalization and 5,000 permutations in the NTSYSpc software (Rohlf, 2000).

\section{RESULTS}

The São José dos Dourados system covers $6,793 \mathrm{~km}^{2}$, most of which $(77.4 \%)$ is pasture. The original vegetation, mostly represented by Semi-Deciduous forests, is found in only $5.6 \%$ of the system (Table 3), and is represented by very degraded, small, and unconnected fragments.

Among the 35 stream reaches sampled, 24 had good SWI, 10 had fair, and only one had poor water quality (Fig. 1a). Expressive differences were not registered stream among orders (mean SWI for first order $=32.8$, second order $=31.0$, third order $=32.5$ ). The physical habitat assessment (Fig. 1b) suggests greater disturbance in the structure of the habitat than the physicochemical conditions of the water. Ten stream reaches had regular PHI (mean score $=98.3$ ), 22 were considered poor (mean score $=69.4$ ), and 3 had very poor habitats $($ score $=28.3)$. The lowest PHI scores were registered for streamside cover, bank stability, bank vegetative stability, and bottom deposition, in that 
TABLE 3

Land use in the São José dos Dourados system (total area $6,793 \mathrm{~km}^{2}$ ), southeastern Brazil.

\begin{tabular}{|l|c|}
\hline \multicolumn{1}{|c|}{ Categories } & Coverage (\%) \\
\hline Pasture & 77.45 \\
\hline Bare soil & 6.24 \\
\hline Perennial crops & 2.40 \\
\hline Remaining natural vegetation & 5.62 \\
\hline Water bodies & 5.18 \\
\hline Sugar cane & 2.15 \\
\hline Urban places & 0.78 \\
\hline Annual crops & 0.16 \\
\hline Reforestation & 0.02 \\
\hline Others & 0.01 \\
\hline
\end{tabular}
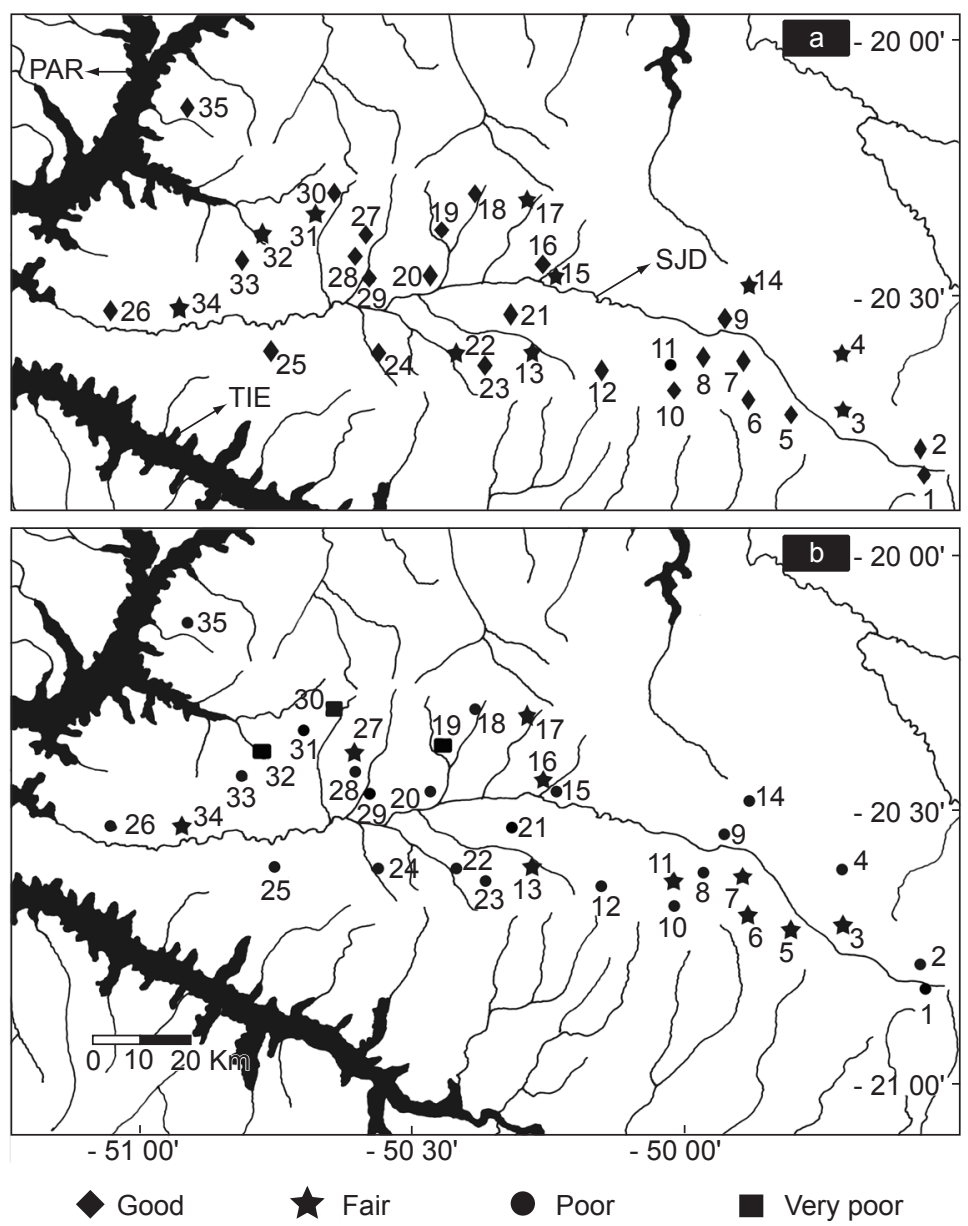

Fig. 1 - Physicochemical condition of water integrity (a) and physical habitat integrity (b) for 35 streams in the São José dos Dourados system, southeastern Brazil. PAR, rio Paraná; SJD, rio São José dos Dourados; and TIE, rio Tietê. 
order. First order streams showed the lowest PHI scores $($ mean $=66.4)$ in comparison to the second $($ mean $=86.7)$ and third order streams $($ mean $=$ 88.5). SWI and PHI were not significantly correlated (Spearman coefficient $=-0.1923, p=0.2685$ ).

Fifty species of fish, belonging to six orders and 18 families (Table 4) were collected, for a total of 7,324 specimens and $19.7 \mathrm{~kg}$. Astyanax altiparanae was the most abundant species (26\% of the total abundance), followed by Poecilia reticulata (18\%), and Knodus moenkhausii (12\%). In terms of biomass, Astyanax altiparanae, Hoplias malabaricus, and Gymnotus carapo were the most important species. Poecilia reticulata, Oreochromis niloticus, and Tilapia rendalii are introductions from outside the upper Rio Paraná system in the first case and outside South America in the two last cases. Knodus moenkhausii, Laetacara sp., and Satanoperca pappaterra represent species whose origin is not clearly defined in the upper rio Paraná basin. The mean richness increased according to stream order ( 5 for first order, 7 for second order, and 12 for third order). Higher abundance and biomass were registered in stream 34 , a second order stretch, whereas lowest abundance and biomass were obtained in stream 12, a first order stretch (Table 5).

Mantel statistics showed that species abundance and habitat descriptors were correlated ( $\mathrm{r}=-0.26024, \mathrm{p}=0.0012, \alpha=0.01)$ and DCA analysis indicated that species gradient is, in general, compatible with physical habitat conditions (Fig. 2). Sites 5, 6, 7, 11, 16, 17, 18, 27, 31, and 34 , all with the best PHI values, were placed in close ecological proximity. Some species reflect such ordination (Fig. 3) and thus can potentially indicate habitat conservation (i.e., Bryconamericus stramineus, Characidium zebra, Hypostomus sp., Imparfinis schubarti, Moenkhausia sanctaefilomenae, Pamphorichthys hollandi, Piabina argentea, Pimelodella avanhandavae, Pseudopimelodus pulcher, and Steindachnerina insculpta). In contrast, in the opposite ordination gradient (Fig. 2), sites 19, 30, and 32 showed the lowest values for PHI. Similarly, species whose optimum reflects this ordination (Fig. 3) could reveal signals of habitat degradation (i.e., Aspidoras fuscoguttatus, Callichthys callichthys, Cichlasoma paranaense, Geophagus brasiliensis, Gymnotus carapo, Knodus moenkhausii, Laetacara sp.,
Oreochromis niloticus, Pyrrhulina australis, Poecilia reticulata, Rivulus pictus, Satanoperca pappaterra, and Tilapia rendalli).

\section{DISCUSSION}

\section{Environmental conditions}

Streams located in the northeastern region of São Paulo State are subject to two major classes of environmental impacts which could negatively affect fish biotic integrity. One of them is organic pollution derived from domestic sewage. Despite the fact that a high percentage (97\%) of sampled streams demonstrated a water condition which was theoretically adequate for fish assemblages, at least three other streams in the basin (not selected in our analysis) received untreated sewage (IPT, 2000), and we believe that this number could be higher and this source of impact must be evaluated at the basin scale. Rapid population growth after 1970 intensified problems associated with urbanization. In 1970, the São José dos Dourados system had 194,000 inhabitants, and by 2010 it is expected to have 213,000 , corresponding to $0.52 \%$ of the total population expected for São Paulo State (IPT, 2000). Despite its low population densities when compared to the rest of the State, only $12 \%$ of the municipalities in the basin had any kind of municipal planning (IPT, 2000). Continuous uncontrolled human growth rates combined with little attention paid to aquatic resources suggest a future decrease in the stream water quality within the basin.

The agency responsible for monitoring surface waterchemical quality in São Paulo State traditionally uses a water quality index (WQI), developed by the National Sanitation Foundation, that employs nine parameters which are combined to classify water for human usage (Braga et al., 2002). Despite being $500 \mathrm{~km}$ long, in the São José dos Dourados river, the WQI is currently calculated for only one site in the main course of the river (Braga et al., 2002), which is clearly insufficient to assess water quality of the entire basin. Seasonal water quality changes were not tested in our study, but in two agricultural streams in a close region, the WQI showed better conditions in the winter than in the summer (Carvalho et al., 2000). The authors attributed these differences to the increased water temperature, turbidity, $\mathrm{pH}$, and fecal bacteria load resulting from land degradation 
TABLE 4

Fish species collected in streams of the São José dos Dourados system, southeastern Brazil.

\begin{tabular}{|c|c|c|}
\hline \multirow[t]{25}{*}{ Characiformes } & Erythrinidae & Hoplias malabaricus (Bloch, 1794) \\
\hline & Lebiasinidae & Pyrrhulina australis Eigenmann \& Kennedy, 1903 \\
\hline & \multirow[t]{12}{*}{ Characidae } & Astyanax altiparanae (Garutti \& Britski, 2000) \\
\hline & & Astyanax fasciatus (Cuvier, 1819) \\
\hline & & Astyanax sp. \\
\hline & & Bryconamericus stramineus Eigenmann, 1908 \\
\hline & & Hemigrammus marginatus Ellis, 1911 \\
\hline & & Moenkhausia sanctaefilomenae (Steindachner, 1907) \\
\hline & & Knodus moenkhausii (Eigenmann \& Kennedy, 1903) \\
\hline & & Oligosarcus pintoi Campos, 1945 \\
\hline & & Piabina argentea Reinhardt, 1866 \\
\hline & & Serrapinnus notomelas (Eigenmann, 1915) \\
\hline & & Serrasalmus marginatus Valenciennes, 1837 \\
\hline & & Planaltina britskii Menezes, Weitzman \& Burns, 2003 \\
\hline & Acestrorhynchidae & Acestrorhynchus lacustris (Reinhardt, 1874) \\
\hline & \multirow[t]{2}{*}{ Crenuchidae } & Characidium zebra Eigenmann, 1909 \\
\hline & & Characidium aff. lagossantense Travassos, 1947 \\
\hline & \multirow[t]{3}{*}{ Curimatidae } & Cyphocharax modestus (Fernández-Yépez, 1948) \\
\hline & & Cyphocharax vanderi (Britski, 1980) \\
\hline & & Steindachnerina insculpta (Fernández-Yépez, 1948) \\
\hline & \multirow[t]{3}{*}{ Anostomidae } & Leporinus friderici (Bloch, 1794) \\
\hline & & Leporinus paranensis Garavello \& Britski, 1987 \\
\hline & & Leporinus striatus Kner, 1859 \\
\hline & \multirow[t]{2}{*}{ Parodontidae } & Apareiodon piracicabae (Eigenmann, 1907) \\
\hline & & Parodon nasus Kner, 1859 \\
\hline \multirow[t]{11}{*}{ Siluriformes } & Pseudopimelodidae & Pseudopimelodus pulcher (Boulenger, 1887) \\
\hline & \multirow[t]{5}{*}{ Heptapteridae } & Cetopsorhamdia iheringi Schubart \& Gomes, 1959 \\
\hline & & Imparfinis mirini Haseman, 1911 \\
\hline & & Imparfinis schubarti (Gomes, 1956) \\
\hline & & Pimelodella avanhandavae Eigenmann, 1917 \\
\hline & & Rhamdia quelen (Quoy \& Gaimard, 1824) \\
\hline & \multirow[t]{3}{*}{ Callichthyidae } & Callichthys callichthys (Linnaeus, 1758) \\
\hline & & Aspidoras fuscoguttatus Nijssen \& Isbrücker, 1756 \\
\hline & & Corydoras aeneus (Gill, 1858) \\
\hline & \multirow[t]{2}{*}{ Loricariidae } & Hypostomus ancistroides (Ihering, 1911) \\
\hline & & Hypostomus sp. \\
\hline \multirow[t]{3}{*}{ Gymnotiformes } & Sternopygidae & Eigenmannia virescens (Valenciennes, 1847) \\
\hline & \multirow[t]{2}{*}{ Gymnotidae } & Gymnotus carapo Linnaeus, 1758 \\
\hline & & Gymnotus inaequilabiatus (Valenciennes, 1842) \\
\hline \multirow[t]{3}{*}{ Cyprinodontiformes } & \multirow[t]{2}{*}{ Poeciliidae } & Pamphorichthys hollandi (Henn, 1916) \\
\hline & & Poecilia reticulata Peters, 1859 \\
\hline & Rivulidae & Rivulus pictus Costa, 1989 \\
\hline Synbranchiformes & Synbranchidae & Synbranchus marmoratus Bloch, 1795 \\
\hline \multirow[t]{7}{*}{ Perciformes } & \multirow[t]{7}{*}{ Cichlidae } & Oreochromis niloticus (Linnaeus, 1758) \\
\hline & & Tilapia rendalli (Boulenger, 1897) \\
\hline & & Cichlasoma paranaense Kullander, 1983 \\
\hline & & Laetacara $\mathrm{sp}$. \\
\hline & & Crenicichla britskii Kullander, 1982 \\
\hline & & Geophagus brasiliensis (Quoy \& Gaimard, 1824) \\
\hline & & Satanoperca pappaterra $($ Heckel, 1840$)$ \\
\hline
\end{tabular}

and higher inputs of sediments and nutrient during the summer wet season.

Decline in the physical habitat conditions is the second class of impairment over fish assemblages within the studied basin. Physical habitat is one of the most important factors affecting the abundance and diversity of aquatic biota (Gorman \& Karr, 1978; Kasyak, 2001), mainly because of influences 
TABLE 5

Location, stream order, richness (S), abundance (N), and biomass (BM, g) of the fish assemblages in 35 streams sampled in the São José dos Dourados system, southeastern Brazil.

\begin{tabular}{|c|c|c|c|c|c|c|}
\hline Streams & Latitude & Longitude & $\begin{array}{c}\text { Stream } \\
\text { order }\end{array}$ & $\mathbf{S}$ & $\mathbf{N}$ & BM \\
\hline 1 & $20^{\circ} 49^{\prime} 20.4^{\prime \prime} \mathrm{S}$ & $49^{\circ} 33^{\prime} 47.0^{\prime \prime} \mathrm{W}$ & 1 & 14 & 95 & 623.1 \\
\hline 2 & $20^{\circ} 46^{\prime} 45.7^{\prime \prime} \mathrm{S}$ & $49^{\circ} 34^{\prime} 52.2^{\prime \prime} \mathrm{W}$ & 2 & 13 & 387 & 843.7 \\
\hline 3 & $20^{\circ} 42^{\prime} 53.0^{\prime \prime} \mathrm{S}$ & $49^{\circ} 42^{\prime} 36.0^{\prime \prime} \mathrm{W}$ & 2 & 9 & 145 & 597.1 \\
\hline 4 & $20^{\circ} 36^{\prime} 29.2^{\prime \prime} \mathrm{S}$ & $49^{\circ} 42^{\prime} 41.9^{\prime \prime} \mathrm{W}$ & 1 & 6 & 71 & 277.8 \\
\hline 5 & $20^{\circ} 43^{\prime} 02.5^{\prime \prime} \mathrm{S}$ & $49^{\circ} 48^{\prime} 41.5^{\prime \prime} \mathrm{W}$ & 2 & 6 & 31 & 173.9 \\
\hline 6 & $20^{\circ} 41 ’ 16.5 ” \mathrm{~S}$ & $49^{\circ} 53^{\prime} 05.7^{\prime \prime} \mathrm{W}$ & 3 & 10 & 86 & 436.1 \\
\hline 7 & $20^{\circ} 37^{\prime} 31.6 ” \mathrm{~S}$ & $49^{\circ} 53^{\prime} 33.4^{\prime \prime} \mathrm{W}$ & 1 & 11 & 102 & 359.6 \\
\hline 8 & $20^{\circ} 36^{\prime} 46.4^{\prime \prime} \mathrm{S}$ & $49^{\circ} 58^{\prime} 05.7^{\prime \prime} \mathrm{W}$ & 1 & 13 & 96 & 821.9 \\
\hline 9 & $20^{\circ} 32^{\prime} 31.4^{\prime \prime} \mathrm{S}$ & $49^{\circ} 56^{\prime} 07.1^{\prime \prime} \mathrm{W}$ & 1 & 8 & 26 & 38.7 \\
\hline 10 & $20^{\circ} 40^{\prime} 27.4^{\prime \prime} \mathrm{S}$ & $50^{\circ} 01 ' 15.9$ ” W & 1 & 13 & 124 & 550.8 \\
\hline 11 & $20^{\circ} 37^{\prime} 53.3^{\prime \prime} \mathrm{S}$ & $50^{\circ} 01^{\prime} 17.4$ " W & 2 & 16 & 99 & $1,350.3$ \\
\hline 12 & $20^{\circ} 38^{\prime} 16.4^{\prime \prime} \mathrm{S}$ & $50^{\circ} 09^{\prime} 09.9^{\prime \prime} \mathrm{W}$ & 1 & 5 & 9 & 15.9 \\
\hline 13 & $20^{\circ} 35^{\prime} 51.3^{\prime \prime} \mathrm{S}$ & $50^{\circ} 16^{\prime} 54.2^{\prime \prime} \mathrm{W}$ & 2 & 16 & 141 & 763.6 \\
\hline 14 & $20^{\circ} 28^{\prime} 32.6^{\prime \prime} \mathrm{S}$ & $49^{\circ} 53^{\prime} 13.1^{\prime \prime} \mathrm{W}$ & 1 & 8 & 112 & 89.2 \\
\hline 15 & $20^{\circ} 27^{\prime} 32.1^{\prime \prime} \mathrm{S}$ & $50^{\circ} 14^{\prime} 33.3^{\prime \prime} \mathrm{W}$ & 1 & 4 & 119 & 205.0 \\
\hline 16 & $20^{\circ} 26^{\prime} 39.2^{\prime \prime} \mathrm{S}$ & $50^{\circ} 15^{\prime} 47.8^{\prime \prime} \mathrm{W}$ & 2 & 16 & 239 & $1,079.0$ \\
\hline 17 & $20^{\circ} 19^{\prime} 45.9^{\prime \prime} \mathrm{S}$ & $50^{\circ} 17^{\prime} 03.9^{\prime \prime} \mathrm{W}$ & 3 & 10 & 82 & 374.4 \\
\hline 18 & $20^{\circ} 18^{\prime} 51.7^{\prime \prime} \mathrm{S}$ & $50^{\circ} 23^{\prime} 04.8^{\prime \prime} \mathrm{W}$ & 1 & 9 & 145 & 856.5 \\
\hline 19 & $20^{\circ} 22^{\prime} 35.0^{\prime \prime} \mathrm{S}$ & $50^{\circ} 27^{\prime} 03.3^{\prime \prime} \mathrm{W}$ & 1 & 3 & 49 & 187.4 \\
\hline 20 & $20^{\circ} 27^{\prime} 46.4^{\prime \prime} \mathrm{S}$ & $50^{\circ} 28^{\prime} 20.6^{\prime \prime} \mathrm{W}$ & 1 & 8 & 185 & 756.4 \\
\hline 21 & $20^{\circ} 31^{\prime} 41.6 " \mathrm{~S}$ & $50^{\circ} 19^{\prime} 15.0^{\prime \prime} \mathrm{W}$ & 3 & 13 & 129 & 259.0 \\
\hline 22 & $20^{\circ} 36^{\prime} 08.9^{\prime \prime} \mathrm{S}$ & $50^{\circ} 25^{\prime} 20.0^{\prime \prime} \mathrm{W}$ & 1 & 7 & 143 & 299.3 \\
\hline 23 & $20^{\circ} 37^{\prime} 43.1^{\prime \prime} \mathrm{S}$ & $50^{\circ} 22^{\prime} 17.8^{\prime \prime} \mathrm{W}$ & 1 & 11 & 271 & $1,810.8$ \\
\hline 24 & $20^{\circ} 36^{\prime} 20.7 ” \mathrm{~S}$ & $50^{\circ} 34^{\prime} 05.0^{\prime \prime} \mathrm{W}$ & 1 & 16 & 345 & $1,408.5$ \\
\hline 25 & $20^{\circ} 35^{\prime} 49.5^{\prime \prime} \mathrm{S}$ & $50^{\circ} 45^{\prime} 29.2^{\prime \prime} \mathrm{W}$ & 2 & 8 & 65 & 109.4 \\
\hline 26 & $20^{\circ} 31^{\prime} 28.8^{\prime \prime} \mathrm{S}$ & $51^{\circ} 02^{\prime} 56.4^{\prime \prime} \mathrm{W}$ & 1 & 9 & 338 & 312.4 \\
\hline 27 & $20^{\circ} 22^{\prime} 58.6^{\prime \prime} \mathrm{S}$ & $50^{\circ} 35^{\prime} 08.6^{\prime \prime} \mathrm{W}$ & 3 & 15 & 111 & 309.1 \\
\hline 28 & $20^{\circ} 25^{\prime} 28.3^{\prime \prime} \mathrm{S}$ & $50^{\circ} 36^{\prime} 10.5^{\prime \prime} \mathrm{W}$ & 1 & 6 & 69 & 361.1 \\
\hline 29 & $20^{\circ} 27^{\prime} 48.5^{\prime \prime} \mathrm{S}$ & $50^{\circ} 35^{\prime} 06.1^{\prime \prime} \mathrm{W}$ & 2 & 4 & 42 & 22.6 \\
\hline 30 & $20^{\circ} 18^{\prime} 29.3 ” \mathrm{~S}$ & $50^{\circ} 38^{\prime} 28.6^{\prime \prime} \mathrm{W}$ & 1 & 7 & 23 & 77.0 \\
\hline 31 & $20^{\circ} 20^{\prime} 51.3 ” \mathrm{~S}$ & $50^{\circ} 40^{\prime} 42.6^{\prime \prime} \mathrm{W}$ & 1 & 15 & 344 & 441.6 \\
\hline 32 & $20^{\circ} 23^{\prime} 11.3^{\prime \prime} \mathrm{S}$ & $50^{\circ} 46^{\prime} 54.3^{\prime \prime} \mathrm{W}$ & 1 & 11 & 1313 & 570.8 \\
\hline 33 & $20^{\circ} 25^{\prime} 53.7^{\prime \prime} \mathrm{S}$ & $50^{\circ} 48^{\prime} 50.3^{\prime \prime} \mathrm{W}$ & 1 & 7 & 129 & 146.7 \\
\hline 34 & $20^{\circ} 31^{\prime} 08.1^{\prime \prime} \mathrm{S}$ & $50^{\circ} 55^{\prime} 37.1^{\prime \prime} \mathrm{W}$ & 2 & 21 & 1495 & $2,717.5$ \\
\hline 35 & $20^{\circ} 09^{\prime} 05.9^{\prime \prime} \mathrm{S}$ & $50^{\circ} 54^{\prime} 46.5^{\prime \prime} \mathrm{W}$ & 1 & 10 & 164 & 430.4 \\
\hline
\end{tabular}

in the availability of sites for feeding, shelter, and reproduction. Ninety-four percent of the sites had poor or very poor physical habitats for supporting fish assemblages, which means substantial deviation from regional reference conditions and indicates high levels of degradation. Furthermore, we observed that many small first order streams listed in our 1970 map database are dry and completely silted.

The lowest PHI scores were obtained for metrics related to riparian vegetation. The replacement of the original forests by pasture in more than $77 \%$ of the region is critical and considers this area as the most degraded in 


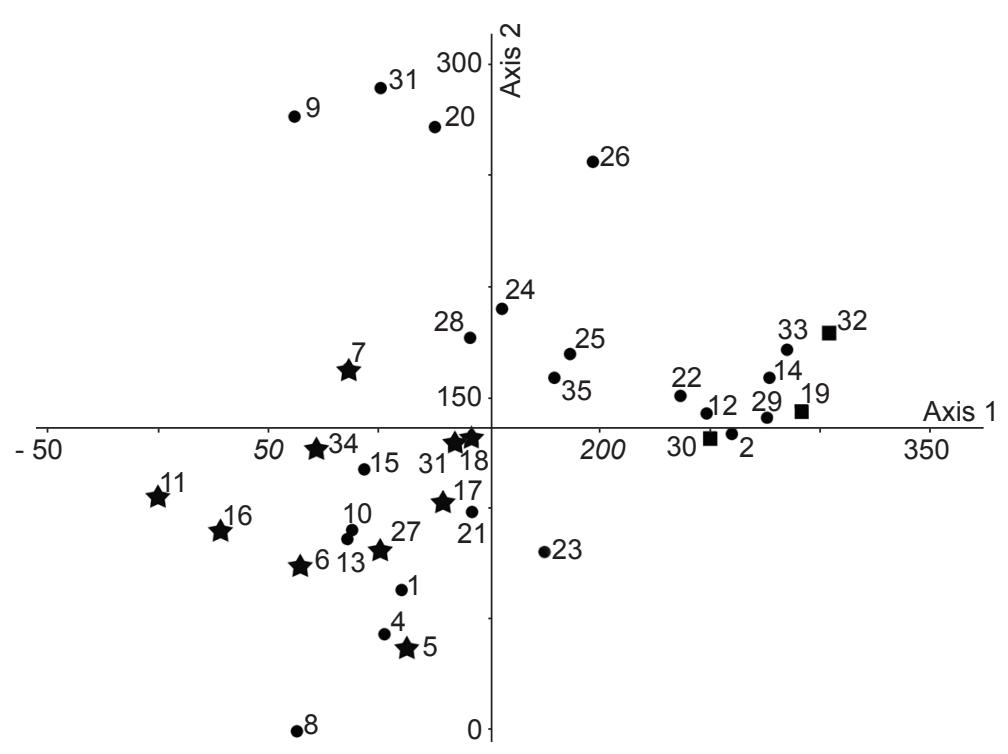

Fig. 2 - Ordination of 35 streams in the São José dos Dourados system (eigenvalues: axis $1=0.625$, axis $2=0.375$ ). Symbols represent Physical Habitat Index: square = very poor; circle = poor; and star = fair.

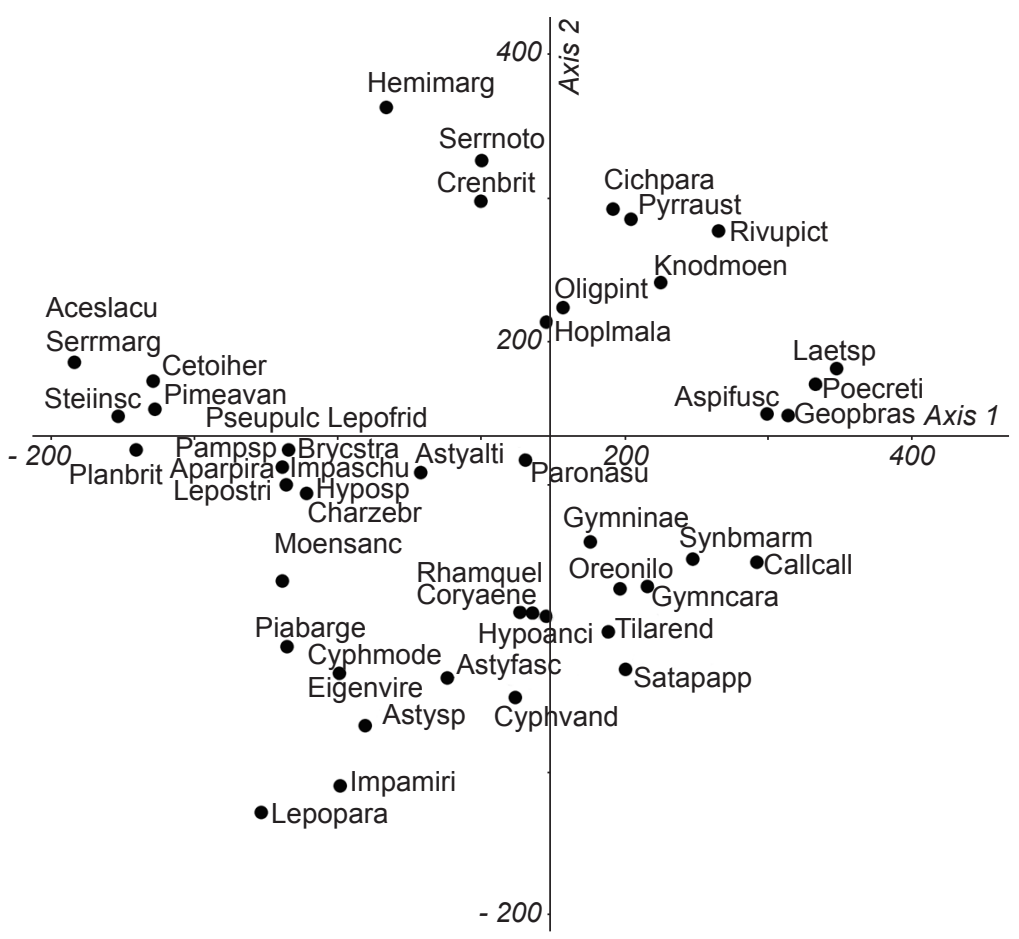

Fig. 3 - Ordination of the 50 species collected in 35 streams of the São José dos Dourados system. Species acronyms refers to the first four letters of the generic and specific names.

the State of São Paulo, since about $12 \%$ of the forested area has been logged during the last ten years (Zorzetto et al., 2003). Deforestation of riparian buffers follows agriculturalization, often without environmental planning or conservation (Rodrigues \& Gandolfi, 2000), increasing thermal 
and nutrient sediment inputs into water courses (Rabeni \& Smale, 1995). Wichert \& Rapport (1998), assessing agricultural watersheds, suggested that enhancement of stream habitat for fish may be achieved by rehabilitating the riparian vegetation. Nonetheless, rehabilitation of riparian areas must be prioritized and intensified in headwaters because the negative impacts of deforestation are more significant in these small water bodies (Gregory et al., 1991), extending along downstream sites (Dale Jones et al., 1999).

\section{Fish fauna}

We evaluated small streams ranging from the first to third order. The mean species number increased according to the stream order, reflecting the predictive power of this descriptor in richness (Matthews, 1998). Along a stream-order, gradient changes in habitat features may reflect species addition, species replacement or changing relative abundances (Gorman \& Karr, 1978). In fact, streams belonging to similar orders have similar physical attributes influenced by peculiar combinations of current, discharge, depth, and substrate, which select for fish species adapted to local features (Matthews, 1998), but in some cases discharge can be a better predictor concerning richness, abundance, and biomass than order (Hughes \& Omernik, 1983). In some cases there is not a unique descriptor that can satisfactorily predict richness because of the sinergistic combination among many of them. In site 34, a second order stretch, we found the highest richness, abundance, and biomass. This site presents high macrohabitat diversity, regular habitat integrity, absence of riparian vegetation, and also a relative amount of debris from aviculture. The two last features may sinergistically increase in situ primary production, and consequently the secondary production. However, this condition may be transitory because the absence of riparian vegetation facilitates sediment intake with further embeddedness of specific microhabitats, thereby further affecting fish assemblage integrity.

Fish abundance correlates with habitat, as indicated by results of the Mantel test. A similar association was also found by Wilkinson \& Edds (2001) in temperate streams and was considered consistent with the hypothesis that community organization depends on environmental factors at the basin-wide scale. We have observed not only correlations between fish abundance and habitat, but also noted that some species have their optimal distribution coincident with the degree of habitat conservation (see Fig. 3) or specific impacts. The land is mainly used for pasture, which means low inputs of nutrients when compared to sewage, and probably also herbicides and pesticides pollution when compared to crops. Thus, the main threat for streams in the region is the physical habitat degradation, mostly substrate simplification and water column reduction, both consequences of the excessive sedimentation or siltation. In spite of being a natural process, siltation is difficult to document, but probably the process has been greatly increased in the studied region since the early last century, after the initial deforestation mainly for coffee plantation (Monbeig, 1998). Either in temperate regions and tropics, high sediment loading is considered the major problem affecting the quality of continental waters and aquatic biota (Lemly, 1982; Dudgeon, 2000).

As examples of fish species particularly associated with good physical habitat conditions, Bryconamericus stramineus and Moenkhausia sanctaefilomenae are considered good water column swimmers (Casatti \& Castro, 1998; Casatti, 2002), depending on adequate habitat volume which decreases with severe siltation. Characidium zebra, Hypostomus sp., Imparfinis schubarti, and Pseudopimelodus pulcher have reophilic preferences (Castro \& Casatti, 1997; personal observations) and must also be negatively affected with siltation due to the embeddedness of the rocky substrate. The toothless Steindachnerina insculpta probably requires special soft substrates to ileophagy (see Fugi et al., 1996 for feeding data) being also negatively affected with siltation.

Through substrate changes, siltation could benefit some species; specifically those adapted to sandy bottoms, as in the case of Knodus moenkhausii, a feeding generalist species (M. Ceneviva-Bastos, personal communication). Reduction of the water column caused by siltation negatively affects water oxygenation and only species with behavioral or physiological strategies can support these changes. In a very silted stream (site 32) Poecilia reticulata represented $62 \%$ of the fish abundance. This species is considered as having expressive phenotipic plasticity (Trexler, 1988), including swimming strategies for 
living in hypoxic waters (Kramer \& Mehegan, 1981). Laetacara sp., Satanoperca pappaterra, Cichlasoma paranaense, and Geophagus brasiliensis, despite presenting distinct feeding tactics, all feed on soft bottoms (Sabino \& Castro, 1990; Casatti et al., 2003; personal observations), largely available in silted streams. In addition, Laetacara sp. was often observed in hypoxic waters (about $1 \mathrm{mg} / \mathrm{l}$ ). Oreochromis niloticus and Tilapia rendalli are species introduced in many aquatic systems worldwide, and the hypoxia tolerance for the first species was documented by Chapman et al. (1995). Native species like Aspidoras fuscoguttatus, Callichthys callichthys, Pyrrhulina australis, Rivulus pictus, and Gymnotus carapo were found in low oxygen waters (Araújo \& Garutti, 2003; Mol, 1994; Shibatta \& Bennemann, 2003; personal observations), a condition often found in shallow silted streams. Thus, ecology of these species and their responses to a range of human interference could reveal reliable metrics for the regional IBI.

The validity of assemblage structure descriptors in the evaluation of the biotic integrity has been discussed by some authors (Fausch et al., 1990). Despite showing indications of disturbance, such methods are strongly influenced by sample size (Fausch et al., 1990). The great challenge in stream biological monitoring is to find, define, measure, and test metrics which can integrate elements and biological processes at several organization levels and reflect the antropic influence on such communities (Karr, 1999). As we demonstrated in this study, routine ecological analysis and ordination techniques, together with natural history and biogeographical knowledge, can give meaningful signals when searching for good biological attributes.

Measurements of physicochemical or habitat conditions cannot replace biological assessments and do not capture all the ways humans influence water resources (Karr \& Chu, 1999). Fish require more than only good chemical or physical conditions to thrive, and such restrict assessments are insufficient to evaluate biological integrity. Our survey is the first attempt to produce a method to assess stream habitat for the region and an alert to resource managers and society about the anthropogenic threats to surface water resources in the São José dos Dourados system. Based on our cursory analysis in this pasture dominated landscape, mitigation efforts should be centered on reversing the degradation in the physical quality of the streams, specifically those of the first order, minimizing physical habitat losses of aquatic biota by rehabilitating riparian vegetation, controlling siltation, and conserving soil. Specifically in the case of riparian zones restoration, this could be an important opportunity for improving connectivity between terrestrial habitats (Becker et al., 2004). In addition, effluents should be treated and land use controls must be developed for, at least, the most populous municipalities in the system. The next steps of this study will include tests on biological attributes in order to develop a fish biotic integrity index. Thus, we expect to obtain a more complete scenario regarding the multiple sources of threats to the streams in this region.

Acknowledgments - We thank members of the Laboratório de Ictiologia UNESP-SJRP for help during field work; Daniela M. L. da Silva for useful information about physicochemical parameters of water; the Geoprocessing Laboratory of São Paulo State Forest Institute for the analysis of satellite images; Rodrigo L. Moura and Tiago Gomes for help with statistical analysis; Robert M. Hughes and Richard P. Vari for helpful suggestions on the manuscript; Departamento de Zoologia e Botânica IBILCE-UNESP for facilities; IBAMA for collecting licence (001/2003); and several landowners for permission to conduct research on their properties. This work was supported by the State of São Paulo Research Foundation (FAPESP) within the BIOTA/FAPESP Program (www.biota.org.br) (98/05072-8, 99/05193-2, 99/05279-4, 00/12939-0, 00/01919-8, 01/13340-7, 02/05996-2, 03/02753-4, 03/02766-9, 03/02767-5, 03/12893-8). RMCC and FL receive grants from CNPq (301309/1991-4, 300474/1999-7).

\section{REFERENCES}

ALLAN, J. D. \& FLECKER, A. S., 1993, Biodiversity conservation in running waters. BioScience, 43: 32-43.

ARAÚJO, R. B. \& GARUTTI, V., 2003, Ecology of a stream from upper Paraná river basin inhabited by Aspidoras fuscoguttattus Nijssen \& Isbrücker, 1976 (Siluriformes, Callichthyidae). Braz. J. Biol., 63: 363-372.

BARBOUR, M. T., GERRITSEN, J., SNYDER, B. D. \& STRIBLING, J. B., 1999, Rapid bioassessment protocols for use in streams and wadeable rivers: periphyton, benthic macroinvertebrates and fish. Second edition. EPA 841-B-99-002. U. S. Environmental Protection Agency; Office of Water, Washington, D.C.

BARCHA, S. F. \& ARID, F. M., 1971, Estudos da evapotranspiração na região norte-ocidental do Estado de São Paulo. Rev. Ciên. Votuporanga, 1: 99-122.

BARTON, D. R., TAYLOR, W. D. \& BIETTE, R. M., 1985, Dimensions of riparian buffer strips required to maintain 
trout habitats in southern Ontario streams. N. Am. J. Fish. Manag., 5: 364-378.

BECKER, F. G., IRGANG, G. V., HASENACK, H., VILELLA, F. S. \& VERANI, N. F., 2004, Land cover and conservation state of a region in the southern limit of the Atlantic Forest (River Maquiné basin, Rio Grande do Sul, Brazil). Braz. J. Biol., 64: 569-582.

BRAGA, B., PORTO, M. \& TUCCI, C. E. M., 2002, Monitoramento de quantidade e qualidade das águas, pp. 635-649. In: A. C. Rebouças, B. Braga \& J. G. Tundisi (orgs.), Águas doces no Brasil: capital ecológico, uso e conservação. Escrituras Editora, São Paulo.

BREN, L. J., 1993, Riparian zone, stream, and floodplain issues: a review. J. Hydrol., 150: 277-299.

CAO, Y., WILLIAMS, D. D. \& WILLIAMS, N. E., 1998, How important are rare species in aquatic community ecology and bioassessment? Limnol. Oceanogr., 43: 1403-1409.

CARVALHO, A. R., SCHLITTLER, F. H. M. \& TORNISIELO, V. L., 2000, Relações da atividade agropecuária com parâmetros físico químicos da água. Química Nova, 23: 618-622.

CASATTI, L., 2002, Alimentação dos peixes em um riacho do Parque Estadual Morro do Diabo, bacia do Alto Rio Paraná, sudeste do Brasil. Biota Neotrop., 2: http://www. biotaneotropica.org.br/v2n2/pt/abstract?article+BN02502 022002 .

CASATTI, L., 2004, Ichthyofauna of two streams (silted and reference) in the Upper Paraná river basin, southeastern Brazil. Braz. J. Biol., 64: 757-765.

CASATTI, L. \& CASTRO, R. M. C., 1998, A fish community of the São Francisco River headwaters riffles, southeastern Brazil. Ichthyol. Explor. Freshwaters, 9: 229-242.

CASATTI, L., LANGEANI, F. \& CASTRO, R. M. C., 2001, Peixes de riacho do Parque Estadual Morro do Diabo, bacia do Alto rio Paraná, SP. Biota Neotrop., 1: http://www. biotaneotropica.org.br/v1n1/pt/abstract?article+BN00201 122001.

CASATTI, L., MENDES, H. F. \& FERREIRA, K. M., 2003, Aquatic macrophytes as feeding site for small fishes in the Rosana Reservoir, Paranapanema River, southeastern Brazil. Braz. J. Biol., 63: 213-222.

CASTRO, R. M. C. \& CASATTI, L., 1997, The fish fauna from a small forest stream of the upper Paraná River Basin, southeastern Brazil. Ichthyol. Explor. Freshwaters, 7: $337-352$.

CASTRO, R. M. C., CASATTI, L., SANTOS, H. F., FERREIRA, K. M., RIBEIRO, A. C., BENINE, R. C., DARDIS, G. Z. P., MELO, A. L. A., STOPIGLIA, R., ABREU, T. X., BOCKMANN, F. A., CARVALHO, M., GIBRAN, F. Z. \& LIMA, F. C. T., 2003, Estrutura e composição da ictiofauna de riachos do Rio Paranapanema, sudeste do Brasil. Biota Neotrop., 3: http://www.biotaneotropica.org.br/v3n1/pt/abs tract?article+BN01703012003.

CASTRO, R. M. C., CASATTI, L., SANTOS, H. F., MELO, A. L. A., MARTINS, L. S. F., FERREIRA, K. M., GIBRAN, F. Z., BENINE, R. C., CARVALHO, M., RIBEIRO, A. C., ABREU, T. X., BOCKMANN, F. A., PELIÇÃO, G. Z., STOPIGLIA, R. \& LANGEANI, F., 2004, Estrutura e composição da ictiofauna de riachos da bacia do Rio
Grande no Estado de São Paulo, sudeste do Brasil. Biota Neotrop., 4: http://www.biotaneotropica.org.br/v4n1/pt/ abstract?article+BN01704012004.

CHAPMAN, L. J., KAUFMAN, L. S., CHAPMAN, C. A. \& MCKENZIE, F. E., 1995, Hypoxia tolerance in twelve species of East African cichlids: potential for low oxygen refugia in Lake Victoria. Cons. Biol., 9: 1274-1288.

CLINNICK, P. F., 1985, Buffer strip management in forest operations: a review. Austr. For. 48: 34-45.

DALE JONES, E. B., HELFMAN, G. S., HARPER, J. O. \& BOLSTAD, P. V., 1999, Effects of riparian forest removal on fish assemblages in southern Appalachian streams. Cons. Biol., 13: 1454-1465.

DUDGEON, D., 2000, The ecology of tropical Asian rivers and streams in relation to biodiversity conservation. Ann. Rev. Ecol. Syst., 31: 239-263.

EASTMAN, J. R., 2001, Idrisi32 - Release 2: Tutorial. Clark University, Worcester, Massachusetts.

FAUSCH, K. D., LYONS, J., KARR, J. R. \& ANGERMEIER, P. L., 1990, Fish communities as indicator of environmental degradation, pp. 123-144. In: S. M. Adams (ed.), Biological indicator of stress in fish. American Fisheries Society, Symposium 8, Bethesda, Maryland.

FEMAT (Forest Ecosystem Management Assessment Team), 1993, Forest ecosystem management: an ecological, economic, and social management. Report of the Forest EcosystemManagementAssessmentTeam.U.S.Government Printing Office 1993-793-071. U. S. Government Printing Office for the Department of Agriculture, Forest Service; U. S. Department of the Interior, Fish and Wildlife Service, Bureau of Land Management, and National Park Service; U.S. Department of Commerce, National Oceanic and Atmospheric Administration and National Marine Fisheries Service; and the U. S. Environmental Protection Agency.

FORBES, S. A. \& RICHARDSON, R. E., 1919, Some recent changes in Illinois River biology. Bull. Illinois Nat. Hist. Survey, 13: 139-156.

FUGI, R., HAHN, N. S. \& AGOSTINHO, A. A., 1996, Feeding styles of five species of bottom-feeding fishes of the high Paraná River. Environ. Biol. Fishes, 46: 297-307.

GARUTTI, V., 1988, Distribuição longitudinal da ictiofauna de um córrego na região noroeste do Estado de São Paulo, Bacia do Rio Paraná. Rev. Bras. Biol., 48: 747-759.

GORMAN, O. T. \& KARR, J. R., 1978, Habitat structure and stream fish communities. Ecology, 59: 507-515.

GREGORY, S. V., SWANSON, F. J., MCKEE, W. A. \& CUMMINS, K. W., 1991, An ecosystem perspective of riparian zones. BioScience, 41: 540-551.

HUGHES, R. M. \& OMERNIK, J. M., 1983, An alternative for characterizing stream size, pp. 87-101. In: T. D. Fontaine \& S. M. Bartell (eds.), Dynamics of lotic ecosystems. Ann Arbor Science, Michigan.

IPT (Instituto de Pesquisas Tecnológicas do Estado de São Paulo), 2000, Diagnóstico da situação atual dos recursos hídricos e estabelecimento de diretrizes técnicas para a elaboração do Plano da Bacia Hidrográfica do São José dos Dourados. Comitê da Bacia Hidrográfica do São José 
dos Dourados e Fundo Estadual de Recursos Hídricos, São Paulo.

KARR, J. R., 1999, Defining and measuring river health. Fresh. Biol., 41: 221-234.

KARR, J. R. \& CHU, E. W., 1999, Restoring life in running waters. Island Press, Washington DC, 206p.

KASYAK, P. F., 2001, Maryland biological stream survey: sampling manual. Maryland Department of Natural Resources, Monitoring and Non-tidal Assessment Division, Annapolis.

KRAMER, D. L. \& MEHEGAN, J. P., 1981, Aquatic surface respiration, an adaptative response to hypoxia in the guppy, Poecilia reticulata (Pisces, Poeciliidae). Environ. Biol. Fishes, 6: 299-313.

LEMLY, D. A., 1982, Modification of benthic insect communities in polluted streams: combined effects of sedimentation and nutrient enrichment. Hydrobiol., 87: 229-245.

LEMES, E. M. \& GARUTTI, V., 2002, Ictiofauna de poção e rápido em um córrego de cabeceira da bacia do Alto Rio Paraná. Comum. Mus. Ciên. Tecnol. PUCRS, Série Zoologia, 15: 175-199.

LILLESAND, T. M. \& KIEFER, R. W., 2000, Remote sensing and image interpretation. John Willey \& Sons, New York, 736p.

LIMA, W. P. \& ZAKIA, M. J. B., 2000, Hidrologia de matas ciliares, pp. 33-44. In: R. R. Rodrigues \& H. L. Leitão Filho (eds.), Matas ciliares: conservação e recuperação. EDUSP /FAPESP, São Paulo.

MATTHEWS, W. J., 1998, Patterns in freshwater fish ecology. Chapman and Hall, New York, 756p.

MAZZONI, R., FENERICH-VERANI, N. \& CARAMASCHI, E. P., 2000, Electrofishing as a sampling technique for coastal stream fish populations and communities in the Southeast of Brazil. Braz. J. Biol., 60: 205-216.

MCCUNE, B. \& MEFFORD, M. J., 1999, PC-ORD. Multivariate analysis of ecological data. Version 4. MjM Software Design, Gleneden Beach, Oregon.

MILLARD, C. J., KAZYAK, P. F. \& BOWARD, D. M., 1999, Lower Susquehanna Basin: environmental assessment of stream conditions. Maryland Department of Natural Resources. Monitoring and Non-tidal Assessment Division, Annapolis, Maryland.

MOL, J. H., 1994, Effects of salinity on distribution, growth and survival of three neotropical armoured catfishes (Siluriformes - Callichthyidae). J. Fish Biol., 45: 763-776.

MONBEIG, P., 1998, Pioneiros e fazendeiros de São Paulo. HUCITEC, São Paulo, 392p.

MYERS, N., MITTERMEIER, R. A., MITTERMEIER, C. G., FONSECA, G. A. B. \& KENT, J., 2000, Biodiversity hotspots for conservation priorities. Nature, 403: 853-858.

NIMER, E., 1989, Climatologia do Brasil. Secretaria de Planejamento e Coordenação da Presidência da República/ IBGE, Rio de Janeiro, 421p.

RABENI, C. F. \& SMALE, M. A., 1995, Effects on siltation on stream fishes and the potential mitigating role of the buffering riparian zone. Hydrobiol., 303: 211-219.
RODRIGUES, R. R. \& GANDOLFI, S., 2000, Conceitos, tendências e ações para a recuperação de florestas ciliares, pp. 235-247. In: R. R. Rodrigues \& H. L. Leitão Filho (eds.), Matas Ciliares: conservação e recuperação. EDUSP /FAPESP, São Paulo.

ROHLF, F. J., 2000, NTSYS 2.1: numerical taxonomic and multivariate analysis system. Exeter Software, New York.

ROTH, N. E., ALlAN, J. D. \& ERICKSON, D. L., 1996, Landscape influences on stream biotic integrity assessed at multiple spatial scales. Landscape Ecology, 11: 141-156.

ROTH, N. E., SOUTHERLAND, M. T., CHAILLOU, J. C., KLAUDA, R. J., KASYAK, P. F., STRANKO, S. A., WEISBERG, S. B., HALL, L. W. \& MORGAN, R. P., 1997, Maryland biological stream survey: development of a fish index of biotic integrity. In Maryland biological stream survey: ecological status of non-tidal stream in six basins sampled in 1995 (Appendix C). Prepared by Versar Inc. for the Maryland Department of Natural Resources, Monitoring and Non-Tidal Assessment Division, Annapolis, Maryland, CNWP-MANTA-EA-97-2.

ROTH, N. E., SOUTHERLAND, M. T., MERCURIO, G. \& VOLSTAD, J. H., 2001, Maryland biological stream survey 2000-2004: Ecological assessment of watersheds sampled in 2000. Prepared by Versar Inc. for the Maryland Department of Natural Resources, Monitoring and Non-Tidal Assessment Division, Annapolis, Maryland, CNWP-MANTA-EA-01-5.

SABINO, J. \& CASTRO, R. M. C., 1990, Alimentação, período de atividade e distribuição espacial dos peixes de um riacho da floresta Atlântica (sudeste do Brasil). Rev. Bras. Biol., 50: 23-36.

SHIBATTA, O. A. \& BENNEMANN, S. T., 2003, Plasticidade alimentar em Rivulus pictus Costa (Osteichthyes, Cyprinodontiformes, Rivulidae) de uma pequena lagoa em Brasília, Distrito Federal, Brasil. Revta. Brasil. Zool., 20: 615-618.

STRAHLER, A. N.,1957, Quantitative analysis of watershed geomorphology. Trans. Am. Geoph. Union, 38: 913-920.

TREXLER, J. C., 1988, Phenotypic plasticity in poeciliid life histories, pp. 201-214. In: G. K. Meffe \& F. F. Snelson (eds.), Ecology and evolution of livebearing fishes (Poeciliidae). Prentice Hall, New Jersey.

TUNDISI, J. G. \& BARBOSA, F. A. R., 1995, Conservation of aquatic ecosystems: present status and perpectives, pp. 365-371. In: T. M. Tundisi, J. G. Tundisi \& C. E. M. Bicudo (eds.), Limnology in Brazil. Academia Brasileira de Ciências / Sociedade Brasileira de Limnologia, Rio de Janeiro.

WICHERT, G. A. \& RAPPORT, D. J., 1998, Fish community structure as a measure of degradation and rehabilitation of riparian systems in an agricultural drainage basin. Environ. Manag., 22: 425-443.

WILKINSON, C. D. \& EDDS, D. R., 2001, Spatial pattern and environmental correlates of a midwestern stream fish community: including spatial autocorrelation as a factor in community analyses. Am. Midl. Nat., 146: 271-289.

ZORZETTO, R., FIORAVANTI, R. \& FERRONI, M., 2003, A floresta renasce. Pesquisa Fapesp, 91: 48-52. 


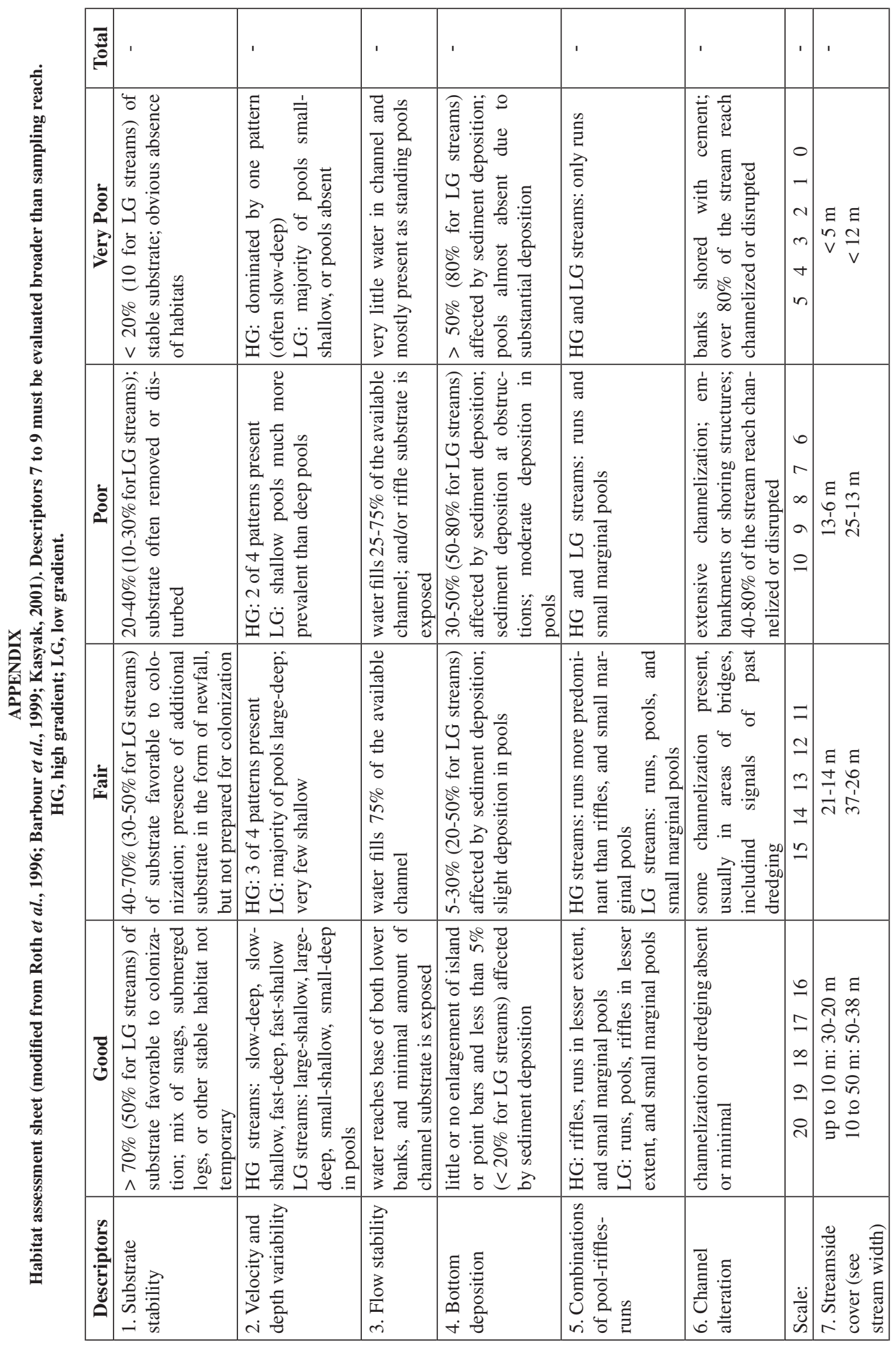




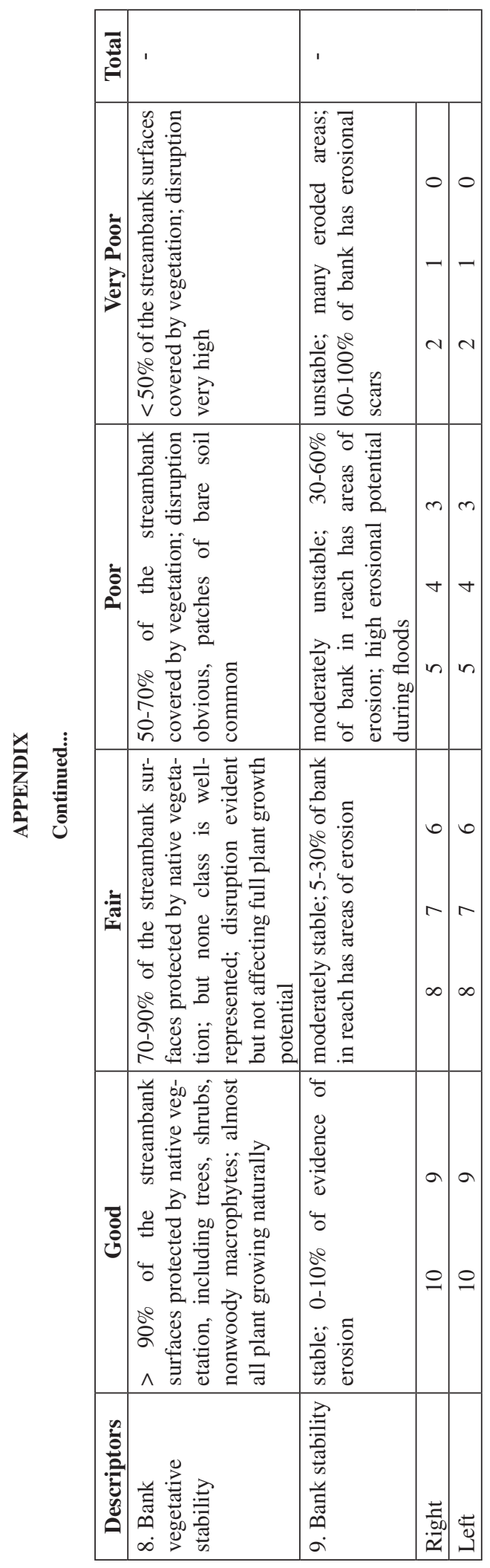

